\title{
ETIKA IT DI INDONESIA STUDI KASUS: CYBERSQUATTING PADA DOMAIN PT. MUSTIKA RATU
}

\author{
Alusyanti Primawati \\ Fakultas Teknik Matematika dan IPA, Program Studi Teknik Informatika \\ Universitas Indraprasta PGRI \\ Email: alus.unindra23@gmail.com
}

\begin{abstract}
ABSTRAK
Dalam artikel ini peneliti membahas mengenai permasalahan kode etik dalam Teknologi Informasi di Indonesia. Pembahasan diungkapkan peneliti melalui studi kasus pada domain PT. Mustika Ratu. Permasalahan yang dikemukakan dalam studi kasus tersebut adalah pelanggaran etika Teknologi Informasi (IT) dengan menyalahgunakan nama domain merek dagang tersebut dan juga merupakan perilaku melanggar hukum khususnya merek dagang salah satu yang dilindungi Negara dalam undangundang Hak Kekayaan Intelektual (HAKI). Domain PT Mustika Ratu dipakai oleh pihak lain yaitu dengan nama domain mustika-ratu.com sedangan domain resmi PT Mustika Ratu adalah mustikaratu.co.id. Dan jika pihak tersebut menyalahgunakan domain merek dagang tersebut maka pihak tersebut telah melakukan cybersquatting.
\end{abstract}

Kata kunci: etika IT, cybersquatting, mustika ratu.

\section{ABSTRACT}

In papper this writers discussed about the problems code of ethics in information technology in Indonesian. Discussion expressed writer through case study in domain PT. Mustika Ratu. The problems mentioned in the study of case is a violation of ethics information technology (IT) with abusing domain names trademark those and is also unlawful behavior particulary trademark one who protected countries in HAKI. The domain PT Mustika Ratu worn by other parties namely by domain names mustika-ratu.com for the domain PT Mustika Ratu. And if parties abusing domain trademark the parties have done cybersquatting.

Keywords: IT Ethics, cybersquatting, mustika ratu.

\section{PENDAHULUAN}

Saat ini internet merupakan alat komunikasi terpopuler, berbagai lapisan masyarakat, mulai dari pengusaha, artis, penyanyi sampai kalangan masyarakat biasa telah menikmati internet, dengan terjadinya peningkatan jumlah pemasangan website atau situs (alamat situs web) di internet, dengan berbagai macam tujuannya, baik untuk tujuan komersial maupun non komersial.

Pemasangan alamat situs web (domain name; nama domain) di internet terus bertambah dari waktu ke waktu, bagai pedang bermata dua, karena selain memberikan kontribusi bagi peningkatan kesejahteraan, kemajuan dan peradaban manusia, sekaligus juga menjadi sarana efektif perbuatan melawan hukum, maupun cybercrime.

Mengapa internet cenderung menjadi sarana efektif untuk melakukan perbuatan melawan hukum? Apakah tidak ada kode etik dalam dunia teknologi informasi?. Untuk menjawab kedua pertanyaan tersebut kita kembali lagi kepada hukum yang ada di Republik Indonesia. Hukum teknologi informasi di Indonesia masih sulit untuk diterapkan khususnya mengenai Hak Kekayaan Intelektual (HAKI). Ini disebabkan keterbatasan pengetahuan sumber daya manusia dalam menerapkan hukum di dunia IT (Teknologi Informasi) khususnya Indonesia. Perkembangan teknologi informasi yang semakin meningkat ini dapat dilihat dari kecenderungan masyarakat yang sudah menggunakan teknologi informasi seperti internet untuk menciptakan dan menyebarkan karya intelektualnya dalam dunia maya, ini bertujuan supaya semua orang tanpa dibatasi daerah ataupun waktu mengetahui informasi tentang karya dan pembuat karya tersebut. Oleh karena itu banyak orang yang memandang bahwa jika informasi dimasukkan dalam dunia internet itu dapat memperoleh banyak keuntungan. Khususnya hal ini diterapkan bagi mereka yang ingin berkarya di e-commerce, e-bussiness, e-library, blog, dan website jejaring sosial. Setiap orang yang menciptakan karya memiliki Hak Kekayaan Intelektual dan hak ini dilindungi oleh Negara. 
Permasalahan yang muncul adalah adanya beberapa orang yang berperilaku tidak etis dengan menyalahgunakan kekayaan intelektual orang lain yang ada dalam dunia cyber melalui tools dalam dunia cyber itu sendiri. Salah satu Hak Kekeyaan Intelektual yang dilindungi adalah merek dagang. Beberapa orang sering menyalahgunakan nama merek dagang orang lain untuk mendapat keuntungan, hal tersebut bisa terjadi dalam dunia maya dengan menggunakan tools dari internet yaitu nama domain (alamat situs web). Hal ini merupakan pelanggaran etika dalam Teknologi Informasi. Berdasarkan latar belakang yang sudah dijelaskan sebelumnya maka dalam hal ini saya sebagai peneliti akan membahas pelanggarangan etika IT pada kasus domain Mustika Ratu. Alamat situs web (domain name; nama domain) di internet, berfungsi sebagai media penghubung antara seseorang atau badan hukum yang memasang informasi dalam situs web internet dengan para pemakai jasa internet. Banyak perusahaan seperti Mustika Ratu menggunakan e-commerrce untuk mempromosikan ataupun memasarkan produk mereka. Mustika Ratu membuat situs web dengan mendaftar nama domainya. Namun ternyata ada pihak yang melalukan cybersquatting terhadap domain Mustika Ratu. Mengapa ini bisa terjadi? Bagaimana solusi yang harus dilakukan Mustika Ratu supaya hal ini tidak terjadi?

\subsection{Tujuan Penulisan}

Adapun tujuan dari penulisan artikel ini adalah untuk menambahkan pengetahuan bagi semua pihak khususnya yang menggunakan teknologi informasi berkaitan etika dalam menggunakan teknologi informasi khususnya dalam penggunaan nama domain dalam alamat situs web baik untuk kepentingan pribadi ataupun perusahaan. Sehingga pemilik situs web dapat waspada terhadap pelanggaran etika dalam dunia internet yang dapat dilakukan oleh pihak lain.

\subsection{Tinjauan Pustaka}

\subsubsection{Keamanan Komputer}

Keamanan komputer merupakan salah satu bagian dari penggunaan komputer yang perlu diperhatikan. Hal ini diperlukan untuk menjamin sumber informasi yang terdapat dalam komputer tetap pada tempat dan tidak menjadi konsumsi umum. Menurut Simarmata [1] keamanan sistem dibagi menjadi 3 yaitu keamanan eksternal, interface pengguna, dan internal. Maka secara mendasar sistem pengamanan komputer yang perlu diamankan adalah pengamanan fisik, akses, data, dan jaringan.

Pengamanan komputer bertujuan untuk menghindari, mencegah, dan mengatasi ancaman-ancaman sistem yang menyerang kerahasiaan, integritas, dan ketersediaan. Berdasarkan fungsi sistem komputer sebagai penyedia informasi ancaman terhadap komputer dikatagorikan menjadi empat [1] yaitu:

a. Interruption

Ancaman yang menyerang ketersediaan informasi.

b. Interception

Ancaman terhadap kerahasiaan informasi dengan melakukan penyadapan

c. Modification

Ancaman terhadap integritas data dengan modifikasi data yang ada.

\section{d. Fabrication}

Ancaman terhadap integritas dengan meniru atau memalsukan pesan sebagai pengirim sehingga penerima menyangka pesan dari pengirim yang dikehendaki.

\subsubsection{Cybersquatting}

Menurut Daniel Suryana [2], Perbuatan melawan hukum di internet, pada gilirannya membuka peluang terjadinya pelanggaran HAKI baik bidang hak cipta, ataupun merek (trademark), maupun bidang hak kekayaan intelektual lainnya, dalam salah satu bentuknya berupa pelanggaran atau penyalahgunaan alamat situs web (domain name; nama domain) berupa cybersquatting, cyberpirate.

Ketika dua prilaku moral berkonflik, kita menghadapi dilema moral. Untuk menentukan bagaimana cara memecahkan sebuah dilemma moral dalam konteks pekerjaan, organisasi, atau profesi, kita menggunakan prinsip-prinsip etika. Kebanyakan perusahaan, perguruan tinggi, dan masyarakat professional mempunyai kode etik resmin yang menggambarkan perilaku etis didalam kelompok tersebut [3]. Demikian juga dunia cyber atau yang kita kenal dengan internet yang merupakan salah satu teknologi informasi juga memiliki kode etik didalamnya.

Definisi yang baku mengenai nama domain belum ditemukan baik dalam peraturan perundangundangan termasuk rancangan Undang-undang, maupun pendapat para ahli. Salah satu peraturan perundang-undangan dalam bentuk regulasi, menyatakan bahwa nama domain 
adalah nama yang digunakan oleh suatu badan, baik swasta maupun pemerintah, ataupun perorangan sebagai identitasnya yang unik di internet. Untuk memudahkan pengoperasian nama domain tersebut, secara internasional telah dibuat singkatan generik (Generic Abbreviation) yang menunjukkan jenis kegiatan atau organisasi alamat yang memiliki domain tersebut, misalnya:".com" untuk Commercial, “.edu” untuk Education Institution, “.gov” untuk Govermen Agencies, “.org” untuk Organization, “.mil” untuk Military, dan “.net” untuk Network. [2].

Pelanggaran kode etik dalam IT khususnya internet cenderung menciptakan kejahatan cyber. Kejahatan cyber seperti cracking, cybersquatting, defacing, cyberporn, dan berbagai ragam bentuk lainnya sudah pernah singgah di Indonesia. Menurut Jhon Preston,dkk [3], mencoba menarik kentungan dari merek dagang orang lain disebut cybersquatting. Sedangkan menurut Sam Ardi [4], Cybersquatting adalah penyalahgunaan domain. Maka dapat disimpulkan cybersquatting merupakan penyalahgunaan domain yang merupakan merek dagang orang lain untuk menarik keuntungan.

\section{METODOLOGI PENELITIAN}

Metode yang digunakan dalam penyusunan artikel ini adalah observasi informasi dalam situs web dan tinjauan pustaka yang mengemukakan kasus terkait etika dalam Teknologi Informasi dan pelanggaran yang terjadi, khususnya dalam melindungi merek dagang yang merupakan Hak Kekayaan Intelektual yang dilindungi oleh Negara.

\section{PEMBAHASAN}

Pertumbuhan bisnis menjadi lebih pesat, akibat munculnya pengaruh perkembangan teknologi informasi, telekomunikasi, media dan informasi. [5]. Salah satunya adalah pemanfaatan internet dengan media informasi berbasis website menjadi hal yang cukup penting untuk dimiliki setiap perusahaan supaya keberadaannya bisnisnya dapat mencakup hingga seluruh dunia. Dengan demikian menjadi cukup mudah bagi sebuah perusahaan memasarkan bisnisnya.

Perusahaan yang membangun sebuah website dan mengaktifkannya dalam layanan internet wajib membuat sebuah nama domain yang mengindentifikasi keberadaan perusahaan tersebut. Sebuah perusahaan memungkinkan membeli nama domain yang menyerupai nama domainnya untuk mendapatkan sebuah keamanan baik bagi konsumen atau perusahaan itu sendiri. Oleh sebab itu nilai sebuah nama domain di Indonesia sudah diatur dalam KUHP dan UU Larangan Praktek Monopoli Persaingan Tidak Sehat [6].

Ancaman keamanan di dunia internet atau sering dikenal dengan Cyber Crime mulai muncul dan berkembang dengan berbagai cara. Salah satunya menyerang hak milik (Againts Property). Nama domain sebuah perusahaan dimungkinkan seperti merek dagang dalam internet, dan perusahaan memiliki hak milik atas merek dagang tersebut. [7].

Cybersquatting merupakan kejahatan dalam dunia maya yang dilakukan dengan melakukan pembelian suatu domain, dimana domain tersebut memiliki penulisan yang mirip dengan satu merek tertentu, perusahaan tertentu yang sangat terkenal dan potensial.

Bagi perusahaan yang sudah memiliki reputasi yang bagus dan dikenal di masyarakat luas, hal ini tentulah sangat meresahkan, karena hal ini berkaitan dengan nama besar dan nama baik perusahaan. Perusahaan yang diincar biasanya perusahaan terkemuka yang sudah mempunyai nama besar.

\subsection{Cara Kerja Cybersquatting}

Kegiatan cybersquatting ini juga sering diartikan sebagai calo website. Karena cybersquatters biasanya akan meminta harga yang jauh lebih besar dari pada harga saat mereka membelinya. Beberapa kasus cybersquatters sering kali menjelek-jelekkan atau menghina sang pemilk nama domain tersebut dengan tujuan pemilik domain mau membeli domain dari mereka.

Selain itu proses perolehan nama domain memiliki sistem first come, first serve artinya siapapun yang mendaftar pertama kali akan dilayani pertama kali, akan tetapi didunia maya sangatlah sulit menemukan yang 'pertama' kali atau perndaftar pertama. Hal inilah yang menjadi salah satu penyebab munculnya Cybersquatting.

Cybersquatting yang dibiarkan atau tidak terindetifikasi oleh pemilik dagang yang memanfaakan website akan mengalami kerugian karena cenderung dapat menjadi sumber ancaman keamanan. Hal tersebut dikarenakan konsumen dimungkinkan tidak sampai pada sumber informasi yang benar yaitu pemilik domain yang benar, melainkan seringkali menuju sumber yang menyerupai domain yang bukan sebenarnya. Keutungan ini diambil dari kemungkinan pengguna internet melakukan kesalahan dalam melakukan interaksi internet seperti kesalahan menulis nama domain atau ketidaktahuaan alamat domain yang benar. Alur ancaman dapat dijelaskan pada gambar 1 . 


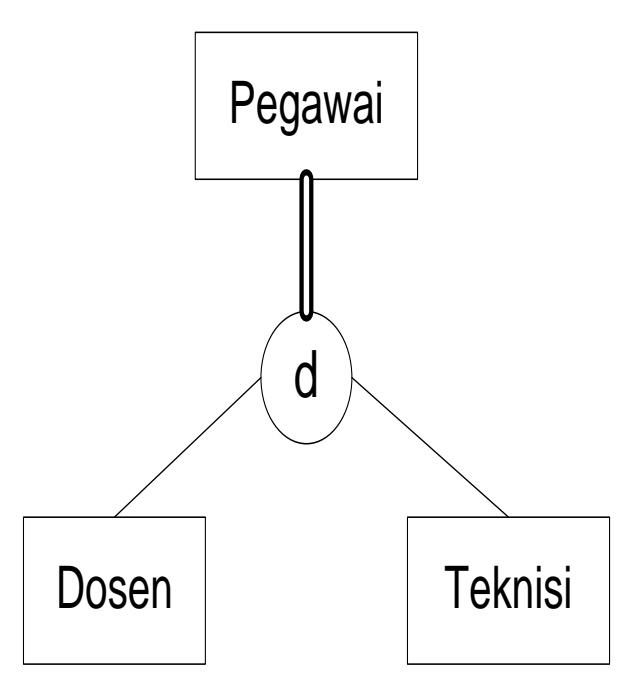

a

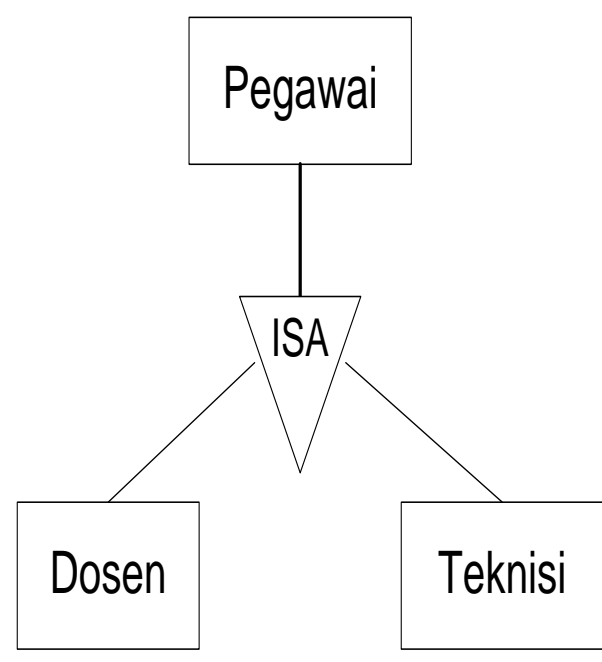

b

\section{Gambar 1. Ancaman dari Cybersquatting}

\subsection{Kasus Mustika-Ratu.com}

Mustika Ratu telah memiliki nama domain Mustika-Ratu.co.id sejak 5 September 1996. Di Indonesia, perkara cybersquatting, dapat dilihat pada kasus mustika-ratu.com, dimana PT.Mustika Ratu tidak dapat mendaftarkan mustika-ratu.com sebagai alamat website-nya, karena telah ada yang pihak lain, telah mendaftarkan mustika-ratu.com sebagai alamat websitenya.

Secara liberal, hal ini etis saja selama pihak tersebut tidak menggunakannya untuk menghancurkan merek dagang tersebut melainkan untuk mendukung pemasaran merek dagang tersebut karena pihak tersebut merasa puas dengan pelayanan dan produk merek dagang tersebut. Namun, secara konservatif, hal tersebut tidak etis dan tetap apapun alasannya merupakan tindakan yang dimungkinkan akan menghancurkan merek dagang orang lain.

Pada kenyataannya padangan konservatif ini yang menguasai cara pandang masyarakat sekarang karena ada pandangan bahwa merek dagang itu memiliki hukum sehingga tidak bisa sembarang pihak yang menggunakan merek dagang tanpa ijin dari pemilik merek dagang tersebut walaupun motivasinya bukan untuk merugikan. Perusahan cenderung mengalami kekuatiran terhadap cybersquatting karena tindakan ini dapat menghancurkan nama perusahaan mereka. Penamaan domain berkaitan erat dengan nama perusahaan dan atau produk (service) yang dimilikinya. Adakalanya suatu nama domain dapat dilindungi dengan hukum merek, karenanya nama domain menjadi kepemilikan dan merupakan salah satu bentuk atau bidang hak kekayaan intelektual (HAKI).

Dalam UU No. 15 Tahun 2001 tentang merek di bawah yurisdiksi Indonesia sudah cukup memadai untuk dijadikan dasar hukum. Pengertian merek dalam UU tersebut adalah tanda berupa gambar, nama, kata, huruf-huruf, angka-angka, susunan warna, dan atau kombinasi dari unsur-unsur tersebut yang memiliki daya pembeda dan digunakan dalam kegiatan perdagangan barang dan jasa. Selain itu juga diperkuat dalam UU ITE (Informasi dan Transaksi Elektronik) bahwa alamat internet penyelenggara negara, orang, badan usaha, dan/atau masyarakat yang dapat digunakan dalam berkomunikasi melalui internet yang berupa kode ataupun susunan karakter yang bersifat unik untuk menunjukan lokasi tertentu dalam internet. [8]

Dalam kasus mustika-ratu.com peneliti berpendapat bahwa pihak lain yang mendaftarkan domain mustika-ratu.com belum tentu bersalah jika tidak merugikan pihak mustika-ratu.com. Namun, tetap tidak etis karena pihak tersebut tidak melakukan perijinan terlebih dahulu terhadap pihak PT.Mustika Ratu sehingga dipertanyakan tujuan dari pihak lain tersebut.

Untuk menghindari pelanggaran etika ini perusahaan perlu waspada khususnya dalam mendaftarkan nama domain, dibutuhkan pengetahuan yang luas mengenai nama domain pada dunia cyber. Bila perlu semua kemungkinan nama domain yang berkaitan dangan nama perusahaan didaftarkan untuk mencagah cybersquatting atau memberikan informasi kepada konsumen alamat situs dengan jelas dan memperingatkan untuk tidak melakukan kesalahan dalam penulisan alamat situs. Misalnya dalam penulisan yang seharusnya .com jadi .co.id/.net/.ac.id/.web, dll atau contohnya saja mustika-ratu jadi mustikaratu/mustika_ratu/ MUST1KA-RATU. 
Jika user tidak memperhatikan hal ini bukan hanya perusahaan yang dirugikan tetapi user ataupun konsumen juga dapat dirugikan. Pentingnya kesadaran pemilik merek dagang untuk mempertahankan dan mengusahakan keamanan dari pemanfaatan merek dagang tersebut. Alasan dari hal ini sudah dikemukakan oleh Yuliati dalam hasil penelitiannya yaitu UU di Indonesia belum mampu menjerat pelaku Cybersquatting karena adanya perbedaan konsep dasar hukum dunia nyata dengan dunia maya.[9].

Kasus serupa bukan hanya terjadi pada PT Mustika Ratu yang merupakan perusahaan kosmetik dalam negeri yang ternama, melainkan juga dialami oleh perusahaan e-commerce pemesanan tikert terbesar seperti Traveloka. Dari sumber [10] dikatakan bahwa pihak traveloka tidak dapat berbuat banyak ketika ada banyak nama domain yang menggunakan nama merek dagangnya karena adanya perlindungan privasi pada website domain palsu tersebut. Dalam hal ini jelas sekali Traveloka dirugikan karena konsumen diarahkan untuk mendapatkan informasi yang tidak terkait dengan pemesanan tiket melainkan situs pornografi. Maka pihak yang melakukan cybersquatting ini diuntungkan.

\section{KESIMPULAN}

Berdasarkan pembahasan sebelumnya dapat disimpulkan bahwa dalam dunia internet rawan terhadap kejahatan cyber karena banyak keterbatasan dari pihak yang bertanggungjawab melindungi. Dan cybersquatting merupakan salah satu pelanggaran etika IT yang merupakan salah satu kejahatan dalam dunia cyber dan ini melanggar hukum yang terkait dengan Hak Kekayaan Intelektual karena merek dagang merupakan salah satu kekayaan intelektual yang dilindungi.

Kesimpulan yang disampaikan diatas mengahasilkan solusi upaya untuk mengatasi pelanggaran etika dalam bentuk cybersquatting tersebut yaitu kewaspadaan dari pihak perusahaan saat mendaftarkan nama domainnya bahwa ada banyak kemungkinan nama domain dari perusahaannya tersebut dan sebaiknya mendaftarkannya untuk menghindari penyalahgunaan domain merek dari pihak lain. Dan konsumen ataupun user harus lebih berhati-hati dalam menuliskan alamat domain dari situs web perusahaan yang dituju. Bagi cybersquatter diharapkan tidak melanjutkan praktik ini karena praktik ini tidak sah oleh Antcybersquatting Consumer Protection Act 1999. Demikian pembahasan mengenai etika dalam Teknologi Informasi (IT) pada kasus PT. Mustika Ratu.

\section{DAFTAR PUSTAKA}

[1] Simarmata, Janer. (2006). Pengamanan Sistem Komputer. Andi: Yogyakarta.

[2] Suryana D. (2006). “Aspek Perlindungan Hak Kekayaan Intelektual Atas Nama Domain di Jaringan Internet”. http://www.blogster.com/dansur/ diakses 26 Juli 2011/ 3.43 PM.

[3] Jhon,P., Sally,P., \& Robert,L P. (2007). Komputer dan Masyarakat: Edisi Pertama. Penerbit Andi: Yogyakarta.

[4] Ardi, S.(2010). "Infrastruktur Internet Indonesia dan Kendala-kendalanya", http://www.bloggerngalam.com/2010/09/11/infrastruktur-internet-indonesia-dan-kendalakendalanya/ diakses 26 Juli 2011/ 2.43 PM.

[5] Rosidawati,I .,\& Santoso E. "Pelanggaran Internet Marketing Pada Kegiatan e-Commerce Dikaitkan dengan Etika Bisnis". journal.kopertis4.or.id/file/PELANGGARAN\%20\%20INTERNET\%20MARKETING.pdf. Diakses 25 November 2015.

[6] Donny, B U. (2011). "Kasus Mustika-Ratu.com: 3 Pertempuran Senilai Rp100 Miliar". http://kambing.ui.ac.id/bebas/v17/com/ictwatch/paper/paper015.htm diakses 26 Juli 2011/12.31 PM.

[7] Sairatu,M., dkk. (2014). "Makalah Cyber Law dan Cyber Crime Pada Etika Profesi Teknologi Informasi dan Komunikasi”. http://epit-ka6f-2014.heck.in/files/makalah-etika-cyber-law.pdf. Diakses 25 November 2015.

[8] Anonim. http://e-journal.uajy.ac.id/327/2/1MIH01725.pdf. Diakses 27 November 2015.

[9] Yuliati. (2003). "Analisa Perbandingan Cybersquatting dan Cyberpiracy menurut UU Merek Dagang dan UU Perlindungan Konsumen di Indonesia dan Amerika Serikat". https://karyatulishukum.files.wordpress.com/2008/12/perbandingan-cybersquatting-dancyberpiracy-di-indonesia-dan-di-as.pdf. Diakses 28 November 2015. 
[10] Anonim. 2015. "Kasus Cybercrime (Analisis Kasus Cybercrime Perkembangan Teknologi Informasi)". https://jimatalisantoso.wordpress.com/2015/01/21/kasus-cyber-crime-analisis-kasuscybercrime-perkembangan-teknologi-komunikasi/. Diakses 23 Februari 2016. 